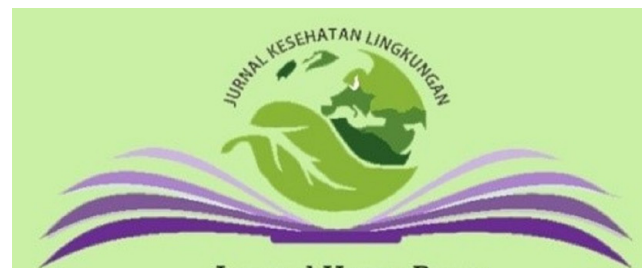

Journal Home Page:

https://e-journal.unair.ac.id/JKL

\section{Jurnal Kesehatan Lingkungan}

Vol. 13 No. 1

DOI: 10.20473/jkl.v13il.2021.17-23

ISSN: 1829 - 7285

E-ISSN: 2040 - 881X

ORIGINAL RESEARCH

\title{
THE ROLE OF SANITARIAN AND SOCIAL-CULTURAL FACTORS IN PROMOTING THE OPEN DEFECATION-
} FREE (ODF) VILLAGE

Anisa Haq Elhanur ${ }^{1 *}$, Putri Nabilah

Ramadhani $^{1}$, R Azizah ${ }^{1}$

${ }^{1}$ Departement of Environmental Health, Public Health Faculty, Universitas Airlangga,

Surabaya 60115, Indonesia

\section{Corresponding Author*:}

anisa.haq.elhanur-2016@fkm.unair.ac.id

\section{Article Info}

Submitted

In reviewed

Accepted

: 13 August 2020

21 September 2020

Available Online

04 January 202

: 31 January 2021

Keywords : ODF Village, non ODF Village, Behavior, Driving Factors

Published by Fakultas Kesehatan Masyarakat Universitas Airlangga

\begin{abstract}
Introduction: Open defecation behavior can be a means of spreading disease. A person's defecation behavior can be influenced by supporting factors provided by health workers, the socio-cultural environment and access to healthy latrine facilities. The aim of this study was to analyze the role of families, community leaders, health workers and the socio-cultural environment on defecating behavior in $O D F$ and non-ODF villages. Methods: This study used quantitative and qualitative observational analytic. The study design was cross sectional design. All people who live on the banks of railway in non $O D F$ and $O D F$ villages were the population in this study. A total of 68 peoples were sampled who determined by themethod proportional random sampling. The independent variables were family support, sanitarian support, community leaders support, the health department team support, socio-culture and population density. The dependent variable was defecation activity. Data were collected by field observation and questionnaires. The collected data were analyzed using the Mann Whitney Test. Results and Discussion: There was no difference in family support $(p=0.661)$, community leaders support $(p=0.122)$, the health department team support $(p=0.555)$. However, there were differences in sanitarian officers support $(p=0.000)$, the socio-cultural environment $(p=0.000)$ and the population density in non ODF villages is higher than in $O D F$ villages. Conclusion: There were differences in sanitarian officers support, the socio-cultural environment and population density between non ODF and ODF villages
\end{abstract}




\section{INTRODUCTION}

The behavior of defecating is still one of the sanitation problem that occur in various countries (1). Based on the data about progress reports on sanitation access of $8,953,719$ households in Indonesia still doing Open Defecation behavior in 2019. The access to sanitation ownership in the East Java region was reaching up to $90.99 \%$. However, the Open Defecation (OD) behavior is still found in 4,196 villages in East Java include Surabaya. Surabaya has not declared as an ODF city even though the access to sanitation has reached $98 \%$. However, there are 17,291 households in Surabaya do OD behavior (2).

Environmental sanitation is a public health effort to maintain the degree of public health (3). Basic environmental sanitation efforts have to be created to achieve good environmental quality, one of them is the presence of latrines to dispose human feces. The availability of clean and healthy latrine for each family is very important in preventing pollution of the surrounding environment. Furthermore, it can be used as an indicator of society's non Open Defecation Free (ODF) behavior (4).

Ketintang Village in Gayungan Sub District already had $100 \%$ latrines access. Jagir Village in Wonokromo Sub District has the lowest precentage of latrine access $(94,57 \%)$. Ketintang Village is an area traversed by railways and has settlements located along the railroad tracks. The residental areas along the railroad tracks are usually in a slum conditions, however it is different from Ketintang Village which able to overcome this by being verified as ODF villages. Most of the residences in Jagir Village are located along the railroad tracks, which are known as slum areas and neglected the health condition. This is proven by the $100 \%$ latrine access under $100 \%$.

OD behavior can cause several problems including health and environmental pollution problems. This is due to the spread of viruses and bacteria caused by polluted environmental conditions (5). The act of disposing of feces directly into the environment can contaminate clean water sources in the local area (6). Changing people's habits regarding to open defecation behavior is not easy, it must be carried out continuously and assisted by the ODF program guidelines (7).

This assistance must be done until the people in the area could think and change behavior to not defecate in inappropriate place (8). There are three factors that are affecting human's behavior, one of them is reinforcing factor which strengthen person's behavior to behave according to social support, peer influence, and people who have influence (9).

This study aims to determine the differences in reinforcing factors (family support, community leaders support, health workers support, and socio-cultural environment support) on defecation activities between non-ODF and ODF villages. This research needs to find out how far the role of family, community leaders, health workers and the socio-cultural environment support on defecation behavior in ODF and non-ODF villages.

\section{METHODS}

This study was a quantitative and qualitative analytic observational study, because it did not provide treatment to respondents. The research used crosssctional design because the variables were one-time examined. The determination of ODF Villages and non ODF Villages was carried out by looking at the data taken from monitoring and evaluation of community-based total sanitation of the Ministry of Health of the Republic of Indonesia in 2019 (2). Therefore, the percentage of latrine access in ODF villages (Ketintang Village) has reached $100 \%$, while for non ODF villages (Jagir Village) was $94.57 \%$. The population were residents who live along the railroad tracks. Based on the data related to latrine ownership report from Jagir Primary Health Care in 2019, hamlet 10 of Jagir Village had the lowest access to latrines compared to other hamlet's, only $74.82 \%$. The three neighborhood's had low latrine access, were neighborhood $5(39.05 \%)$, neighborhood $6(42.1 \%)$ and neighborhood 7 (42.65\%) with total 215 families living in the area. In contrast to hamlet 3 of Jagir Village, Ketintang Village became role model related to cleanliness and the living environment. There were 147 families in neighborhood 6 and 7 live along the railroad tracks. People who lived along the railroad tracks were chosen because the areas tend to be densely populated and slum environment. samples taken for the non ODF were 68 respondents and 60 respondents for ODF village (38 respondents from neighborhood 6 and 22 from neighborhood 7 ). The inclusion criteria were father or mother in the family, living in the study area and willing to fill out the research questionnaire with a minimum age of 17 years. The number of samples in ODF and non-ODF villages was different because of different population on each neighborhood.

The variables tested included family support, sanitarian workers support, community leaders support, the health service team support, socio-culture and population density. Based on this support, it can be seen the influence of family support, sanitation officers support, community leaders support, and health department 
team support on defecation activities. The socio-cultural environment variable included habits related to the use of latrines. The variables were measured by interview method with a questionnaire guide.

The data collection process was done by observations, supported by secondary data from village, and interviews assisted by a questionnaire. The data analysis technique used univariate and bivariate technique. Univariate technique was used to describe each variable. The bivariate technique was used to compare two or more variables, namely the MannWhitney Utest test.

This research has passed an ethical review with registration number 109/HRECC.FODM/III/2020 at the Faculty of Dentistry, Universitas Airlangga in March 2020.

\section{RESULTS}

The Results of Frequency Distribution of Respondents' Reinforcing Factors in ODF and NonODF Villages

Based on Table 1, there were 27 respondents $(45.00 \%)$ with good reinforcing factor on family support, 40 respondents $(66.66 \%)$ with sanitarian officers support, and 24 respondents $(40.00 \%)$ with community leaders support. All respondents stated that the local sociocultural support was good. Meanwhile, 66 respondents $(97.06 \%)$ stated that there was lack of support from the public health officer team.

Table 1. Frequency Distribution of Reinforcing

Factors Between ODF Villages and Non-ODF Villages In 2020

\begin{tabular}{|c|c|c|c|c|c|c|c|}
\hline \multirow{3}{*}{ Variable } & \multicolumn{6}{|c|}{ ODF } & \multirow{3}{*}{ Total } \\
\hline & \multicolumn{2}{|c|}{ Good } & \multicolumn{2}{|c|}{ Enough } & \multicolumn{2}{|c|}{ Less } & \\
\hline & n & $\%$ & n & $\%$ & n & $\%$ & \\
\hline \multicolumn{8}{|l|}{ ODF Village } \\
\hline Family Support & 27 & 45.00 & 24 & 40.00 & 9 & 15.00 & \multirow{5}{*}{60} \\
\hline $\begin{array}{l}\text { Support from } \\
\text { Sanitation Officers }\end{array}$ & 40 & 66.66 & 19 & 31.66 & 1 & 1.68 & \\
\hline $\begin{array}{l}\text { Support from } \\
\text { Community Leaders }\end{array}$ & 24 & 40.00 & 23 & 38.33 & 13 & 21.67 & \\
\hline $\begin{array}{l}\text { Support from The } \\
\text { Health Department } \\
\text { Team }\end{array}$ & 1 & 1.67 & 2 & 3.33 & 57 & 95.00 & \\
\hline Social Culture & 60 & 100.00 & 0 & 0.00 & 0 & 0.00 & \\
\hline \multicolumn{8}{|l|}{ Non-ODF Village } \\
\hline Family Support & 38 & 55.96 & 15 & 22.05 & 15 & 22.05 & \multirow{5}{*}{68} \\
\hline $\begin{array}{l}\text { Support from } \\
\text { Sanitation Officers }\end{array}$ & 29 & 42.4 & 11 & 14.19 & 28 & 41.17 & \\
\hline $\begin{array}{l}\text { Support from } \\
\text { Community Leaders }\end{array}$ & 23 & 33.82 & 20 & 29.41 & 25 & 36.77 & \\
\hline $\begin{array}{l}\text { Support from The } \\
\text { Health Department } \\
\text { Team }\end{array}$ & 1 & 1.47 & 1 & 1.47 & 66 & 97.06 & \\
\hline Social Culture & 34 & 50.00 & 31 & 45.58 & 3 & 4.42 & \\
\hline
\end{tabular}

The population density in Ketintang Village is 584.88 people $/ \mathrm{km}^{2}$. Whereas in non ODF villages, there were 68 respondents with good reinforcing factor on family support variable as many as 38 respondents (55.96\%),
29 respondents (42.4\%) with sanitarian officers support and 34 respondents $(50.00 \%)$ with good socio-culture. Meanwhile, the variable of community leaders as many as 25 respondents $(36.77 \%)$ and the health department team support as many as 66 respondents $(97.06 \%)$.

The Population Density Level in Jagir Village was $22,199.00$ people $/ \mathrm{km}^{2}$, with an administrative area of $101,175 \mathrm{Ha}$ and a population of 22,421 people.

\section{Cross Tabulation of Difference between Reinforcing Factors of Respondents in Non-ODF and ODF Villages}

Based on the test results in Table 2, there was no difference in family support $(p=0.661)$, the health service team support $(p=0.555)$, community leaders support $(p=$ 0.122 ) between ODF and non ODF. However, there were differences in support provided by sanitarian officers $(p$ $=0.000)$ and socio-cultural support $(p=0.000)$ between ODF and non-ODF villages). Based on the data obtained from the village profile, it can be seen that the population density in the village is not yet ODF of 22,199.00 people/ $\mathrm{km}^{2}$. For ODF villages (having a population density of 584.88 people $/ \mathrm{km}^{2}$. Based on this, it can be seen that there is a difference in population density between villages which are not yet ODF and ODF villages. In this case, ODF villages have a lower density than villages that are not yet ODF.

Table 2. Frequency Distribution Differences in Reinforcing Factors between ODF Villages And Non-ODF Villages In 2020

\begin{tabular}{|c|c|c|c|c|c|}
\hline \multirow{3}{*}{ Variable } & \multicolumn{4}{|c|}{ ODF } & \multirow{3}{*}{$\begin{array}{c}\text { P } \\
\text { Value }\end{array}$} \\
\hline & \multicolumn{2}{|c|}{$\begin{array}{c}\text { ODF } \\
\text { Village }\end{array}$} & \multicolumn{2}{|c|}{$\begin{array}{c}\text { Non-ODF } \\
\text { Villlage }\end{array}$} & \\
\hline & $\mathbf{n}$ & $\%$ & n & $\%$ & \\
\hline \multicolumn{6}{|l|}{ Family Support } \\
\hline Good & 27 & 45.00 & 38 & 55.96 & \\
\hline Enough & 24 & 40.00 & 15 & 22.05 & 0.661 \\
\hline Less & 9 & 15.00 & 15 & 22.05 & \\
\hline \multicolumn{6}{|c|}{$\begin{array}{l}\text { Support from Sanitation } \\
\text { Officers }\end{array}$} \\
\hline Good & 40 & 66.66 & 29 & 42.64 & \\
\hline Enough & 19 & 31.66 & 11 & 14.19 & 0.000 \\
\hline Less & 1 & 1.68 & 28 & 41.17 & \\
\hline \multicolumn{6}{|c|}{$\begin{array}{l}\text { Support from Community } \\
\text { Leaders }\end{array}$} \\
\hline Good & 24 & 1.67 & 23 & 33.82 & \\
\hline Enough & 23 & 3.33 & 20 & 29.41 & 0.122 \\
\hline Less & 13 & 95.00 & 25 & 36.77 & \\
\hline \multicolumn{6}{|c|}{$\begin{array}{l}\text { Support from The Health } \\
\text { Department Team }\end{array}$} \\
\hline Good & 1 & 1.67 & 1 & 1.47 & \\
\hline Enough & 2 & 3.33 & 1 & 1.47 & 0.555 \\
\hline Less & 57 & 95.00 & 66 & 97.06 & \\
\hline \multicolumn{6}{|l|}{ Social Culture } \\
\hline Good & 60 & 100.00 & 34 & 50,00 & \\
\hline Enough & 0 & 0 & 31 & 45.58 & 0.000 \\
\hline Less & 0 & 0 & 3 & 4.42 & \\
\hline Total & 60 & 100.00 & 68 & 100.00 & \\
\hline
\end{tabular}




\section{DISCUSSION}

Analysis of the Difference Between Family Support and Community Leaders between ODF and Non-ODF Villages

The upport from family and community leaders is one of the important things in this research, because both of them are the smallest scope which is close to the community. Family support is very important, because someone will have good behavior if they get support from a good family too (10). If the family has implemented proper and healthy latrine usage behavior, it will be easy for other family members to apply the same thing (11). Support from local community leaders is also very important. A community figure is someone who becomes role model, respected and has influence on their surroundings. Formal community leaders are selected and appointed by state institutions such as the camat and lurah. The informal community figure is recognized by the community because deemed appropriate to lead a group of peoples (12). Community leader plays a role in providing appeal to not defecate in inappropriate place. This support is expected to change people's defecating behaviors (13).

The family support got value of $p=0.661$, means that there was no difference in the support provided by the family between non ODF and ODF villages. These results were not in line with a research conducted in Jatibarang Subdistrict, Brebes Regency in 2019 whichp value of $=0.001$, there was significant relationship between family support and the use of latrines (11). Another study conducted in Pulosari Subdistrict, Pemalang Regency in 2016 stated that there was relationship between defecation behavior and family support(12). Table 2 also explained that $p$ value obtained from community leaders support was 0.122 , there was no difference in community leaders support between non-ODF and ODF villages. It was in line with the research results in Bugis Village, Tanjungpinang City, which showed there was no relationship between the role of community leaders and latrines ownership (14). Research conducted in the fisherman village of Tamba chlorok, Semarang in 2017, which obtained $p$ value $=$ 0.654 , the local villagers stated the support provided by community leaders was still low (15). In contrast to these results, a research conducted at the Sawan II Public Health Center in Buleleng Regency in 2020 found a significant relationship between defecation behavior and community leaders support $(p=0.000)(16)$.

Based on the results, most people living in non and ODF villages received equal support from their families regarding to stop open defecation behavior. Especially in non-ODF villages, the family has provided support in reminding and prohibiting defecation, providing information related to the importance of healthy latrines, so that open defecation can be eliminated. the habit of open defecation could not be changed by family support. In addition, in-depth interviews conducted with the Head of hamlet 10 and the Head of neighborhood 5, 6 , and 7 Jagir village as community leaders. All hamlet's and neighborhood's heads stated that they had provided support to the community in providing related information such as the importance of defecating in healthy latrines, an appeal for healthy latrines, and the existence of healthy latrine savings program in the area. The local community leaders support has not yet realized, due to limited land and low levels of community income.

\section{Analysis of Differences in Socio-Cultural Environment and Population Density Between ODF and Non-ODF Villages}

The development of socio-cultural transformation in Indonesia continues to change every year, this is adjusted to the changes of times. One of them is the presence of energy and strong force for society to continue to work out in making changes for the better, it becomes strength in the socio-cultural environment (17). Not only cultural transformation, population growth in Indonesia also continues to increase. This condition can be seen from urban conditions that are increasingly populated with housing and settlements due to high population density (18). Population density is a term to address the number of people compared to the total land area. The total population in each $\mathrm{km}^{2}$ or administrative area is called crude population density (CPD) (19). Therefore, population density can describe the average population at each $\mathrm{km}^{2}(20)$.

Based on the results in Table 2, the value of $p=0.000$, there were differences in the socio-cultural environment between non-ODF villages and ODF villages. The result was in line with 3 other studies which done in Empakan Village, Kayan Hulu District in 2017, $p$ value $=0.000$, there was relationship between culture and ownership of healthy latrines (21). Furthermore, research conducted in the Village of Sumbersari Metro Selatan in 2016, $p$ value $=0.001$ which mean that the socio-cultural environment had an influence on stopping defecation in Purwosari Village, Metro City (22). The third research carried out in Lermatang Village, West Southeast Maluku Regency in 2019 also stated that socio-cultural environmental factors played an important role in community defecation behaviors (23). the population density in non-ODF villages reached 22,199.00 people $/ \mathrm{km}^{2}$, greater than the ODF village, which was 584.88 people $/ \mathrm{km}^{2}$. Population density can lead to various demographic problems such as 
the decreased of population quality, food sufficiency, decreased of productivity and other crucial issues related to employment (24).

Based on the results in non-ODF villages, the community prefered to build latrines without a septic tank, it became unhealthy habit. this area had a fairly high population density, with average $24 \mathrm{~m}^{2}$ to $36 \mathrm{~m}^{2}$ per house that tends to be narrow, so the opportunity to build healthy latrines is reduced. There was different with the ODF village where the entire community already had healthy latrines, so that no one opendefecated. In addition, in ODF villages, there was a sense of shame in the community to open defecate. There was still sufficient land so that possible to build healthy latrines in their own residence.

\section{Analysis of the Differences in Health Officers Support Between Non-ODF and ODF Villages}

In this study, health workers were divided into two, local health center sanitarian workers and health service officers. Sanitarians have very important role in carrying out sanitation inspections to monitor and assess the conditions of latrine, as well as monitoring the presence of pollution that possible to cause disease (25). In addition, sanitarian workers also have very important role in shaping the community mindset to have shame, fear of being sick, disgust and guilt when open defecated (26). Another health worker who has important role in shaping the people's behavior is the local health department team. Based on the Regulation of the Mayor of Surabaya Number 48 of 2016, service is an element of government implementation in the health sector. The health office has several fields, one of them is public health including public health development and environmental health. Some of the tasks include preparing implementation materials and technical instructions in terms of community development and health promotion, and preparing supervision and control in sports division, environmental health and occupational health (27). In addition, based on Regulation of Ministry of Health of Republic Indonesia No.3/MENKES/2014 about Community Based Total Sanitation, the health department team has a program, called the CommunityBased Total Sanitation program to improve the degree of public health (28).

Based on the results in Table 2, the value of $p=0.000$, there was difference in sanitarian officers support in non-ODF and ODF villages. The results were in line with the research conducted in Ciaro Village in 2020 stated that sanitarian workers have significant role in triggering to stop open defecation behavior in the community (29). The test results related to the role of the health service team obtained $p$ value $=0.555$, there was no difference health service team support related to defecation activities both in non-ODF and ODF villages. The result was in line with the research conducted in Air Pinang Village, Simeulue Regency, which $p=0.007$, health workers have significant role in using family latrines (30). However, it was different from the results of research conducted in Gunungsari Village (2016), p value of 0.232 , there was no relationship between community behavior and defecation in latrines with health workers support (12).

Based on the results, $41.17 \%$ respondents in non-ODF village stated the lack of local health workers support. the support given by sanitarian officers was limited in reminding and prohibiting the defecation practice. In contrast to the ODF village, $66.66 \%$ of the respondents felt the sanitarian officers support was good. the local sanitarian workers support of giving advice to build healthy latrines and giving information about the importance of stoppingopen defecation. In addition, the role of sanitarian officers in ODF villages has received a lot of support from local village officials as well as the "Jamban Sehat" means healthy latrine program created by PT Pembangkit Jawa Bali related to Community Based Total Sanitation.

The community had lack of support from the health department team, because the health service team has never been involved directly in helping or providing support to the community. This study limited in taking the initial data collection at the relevant Puskesmas due to the pandemic. In addition, this study only involved one non-ODF village and one ODF village which still cannot describe the general conditions in Surabaya. Therefore, the next research should be conducted in several nonODF and ODF villages in Surabaya to obtain more informations

\section{CONCLUSION}

The lack of sanitarian officers support and the local socio-cultural environment regarding to ownership and the use of healthy latrines in non-ODF village. The role of sanitarian officers needed by the community to provide education on the negative impact of disease when they did defecation activities. In addition, the support of the socio-cultural environment has important role in shaping a person's attitude in order to feel ashamed of doing open defecation to lead a healthy life. The population density which is higher than the available land area, causes open defecation practice in nonODF. In ODF village, the community has received good support from sanitarian officials and the socio-cultural environment. In addition, ODF villages are supported by 
the assistance provided by third parties related to the construction of healthy latrines. To be able to achieve the target of the ODF village, it requires assistance and synergy between related parties and the community. The public health sanitarian officers should be able to provide additional support to the community, such as providing more intensive assistance.

\section{REFERENCES}

1. Agustiyaningsih $T$, Kurnia $A D$, Larasati $R Y$. Hubungan Pengetahuan tentang Jamban Sehat dan Lingkungan Fisik dengan Perilaku Buang Air Besar Sembarangan. Dunia Keperawatan Jurnal Keperawatan dan Kesehatan. 2020;8(2):130-139. http://dx.doi.org/10.20527/dk.v8i2.7960

2. Ministry of Health of Republic Indonesia. Community Based Total Sanitation. Jakarta: Ministry of Health of Republic Indonesia;2019. http://monev.stbm. kemkes.go.id/monev/

3. Desmawati, Ari Pristiana OH. Hubungan Personal Hygiene dan Sanitasi Lingkungan dengan Kejadian Skabies DI Pondok Pesantren Al Kautsar Pekanbaru. J Online Mahasiswa. 2015;2(1):628637. https://jom.unri.ac.id/index.php/JOMPSIK/ article/view/8336

4. Sidhi A, Raharjo M, Dewanti N. Hubungan Kualitas Sanitasi Lingkungan dan Bakteriologis Air Bersih terhadap Kejadian Diare pada Balita di Wilayah Kerja Puskesmas Adiwerna Kabupaten Tegal. J Kesehatan Masyarakat. 2016;4(3):665-676. https://ejournal3.undip.ac.id/index.php/jkm/article/ viewFile/13480/13036

5. Nugraha MF. Dampak Program Sanitasi Total Berbasis Masyarakat (STBM) Pilar Pertama Di Desa Gucialit Kecamatan Gucialit Kabupaten Lumajang. J Kebijakan dan Manajemen Publik. 2015;3(2):44-53. http://journal.unair.ac.id/filerPDF/ kmp62b069aeb2full.pdf

6. Rahmadani RD, Ridlo IA. Perilaku Masyarakat dalam Pembuangan Tinja Ke Sungai Di Kelurahan Rangkah , Surabaya. Indonesian $J$ Health Promotion and Health Education. 2020;8(1):87-98. http://dx.doi.org/10.20473/jpk.V8.11.2020.87-98

7. Sukma H, Mursid, Nurjazuli. Hubungan Pengetahuan, Sikap Bab, Dan Kepemilikan Septic Tank Dengan Status ODF (Open Defecation Free) di Kecamatan Candisari Kota Semarang. J Kesehatan Masyarakat. 2018;6(6):143-149. https://ejournal3. undip.ac.id/index.php/jkm/article/view/22169

8. Ganing A, Hairuddin MC. Perilaku Masyarakat Terhadap Sanitasi Total Berbasis Masyarakat di Kabupaten Majene. J Kesehatan Manarang. 2016;2(2):66-71. https://doi.org/10.33490/jkm. $\underline{\mathrm{v} 2 \mathrm{i} 2.17}$

9. Glanz K, Rimer BK, Viswanath K. Health Behavior and Health Education $5^{\text {th }}$ Edition Theory, Research, and Practice. San Francisco: Jossey-Bass Books;2008.

10. Qudsiyah WA, Pujiati RS, Ningrum PT. Faktor-
Faktor yang Berhubungan dengan Tingginya Angka Open Defecation (OD) di Kabupaten Jember (Studi di Desa Sumber Kalong Kecamatan Kalisat). J Pustaka Kesehatan. 2015;3(2):362-369. https:// jurnal.unej.ac.id/index.php/JPK/article/view/2679

11. Apriyanti L, Widjanarko B, Laksono B. Faktor-faktor yangMempengaruhiPemanfaatan JambanKeluarga di Kecamatan Jatibarang Kabupaten Brebes. J Promosi Kesehatan Indonesia. 2018;14(1):1-14. https://doi.org/10.14710/jpki.14.1.1-14

12. Wijayanti AK, Widagdo L, Shaluhiyah Z. FaktorFaktor yang Berhubungan dengan Buang Air Besar di Jamban di Desa Gunungsari Kecamatan Pulosari Kabupaten Pemalang. J Kesehatan Masyarakat. 2016;4(1):450-460. https://ejournal3.undip.ac.id/ index.php/jkm/article/view/11855

13. Dwiana A, Herawaty L. Determinan Perilaku Buang Air Besar Pada Masyarakat Pesisir Di Kabupaten Buton Selatan. Berita Kedokteran Masyarakat. 2017;33(6):273-276. https://doi.org/10.22146/ bkm.23539

14. Samosir K, Ramdhan FS. Peranan Perilaku Dan Dukungan Tokoh Masyarakat terhadap Kepemilikan Jamban Sehat di Tanjungpinang. J Kesehatan. 2019;12(1):168-174. https://doi.org/10.32763/juke. v12i1.115

15. Kurniawati LD, Windraswara R. Faktor-Faktor Yang Berpengaruh terhadap Perilaku Kepala Keluarga dalam Pemanfaatan Jamban di Pemukiman Kampung Nelayan Tambaklorok Semarang. Public Healt Perspective J. 2017;2(1):72-79. https:// journal.unnes.ac.id/nju/index.php/phpj/article/ view/10997

16. Meriantini NK. Hubungan Karakteristik Kepala Keluarga dengan Perilaku Buang Air Besar Sembarangan (BABS) di Wilayah Kerja Puskesma Sawan II Kabupaten Buleleng Tahun 2020. Skripsi. Denpasar: POLTEKKES Denpasar; 2020.

17. Kistanto NH. Transformasi Sosial-Budaya Masyarakat Indonesia. J Kajian Kebudayaan. 2018;13(2):169-178. $\quad$ https://doi.org/10.14710/ sabda.13.2.169-178

18. Wihadanto A, Barus B, Achsani NA, Bratakusumah DS. Analisis Karakteristik dan Penilaian Tingkat Kekumuhan Kawasan Permukiman 'Kampung Braga' - Kota Bandung. J Region Rural Development Planning. 2017;1(2):132-144. https:// doi.org/10.29244/jp2wd.2017.1.2.132-144

19. Central Statistic Agency. Social and Population. Jakarta: Central Statistic Agency of Indonesia;2019. https://www.bps.go.id/istilah/index

20. Ruhimat M. Tekanan Penduduk Terhadap Lahan di Kecamatan Sukaraja Kabupaten Sukabumi. J Pendidikan Geografi . 2016;15(2):59-65. https:// doi.org/10.17509/gea.v15i2.3548

21. Putra GS, Selviana. Faktor-Faktor Yang Berhubungan Dengan Kepemilikan Jamban Sehat di Desa Empakan Kecamatan Kayan Hulu. J Kesehatan Masyarakat Khatulistiwa. 2017;4(3):238-243. http://dx.doi.org/10.29406/ jkmk.v4i3.866 
22. Febriani W, Samino, Sari N. Faktor yang Mempengaruhi Perubahan Perilaku Stop Buang Air Besar Sembarangan (BABS): Studi Pada Program STBM di Desa Sumbersari. Metro Selatan 2016. J Dunia Kesmas. 2016;5(3):121-130. http:// ejurnalmalahayati.ac.id/index.php/duniakesmas/ article/view/467

23. Dewi $\mathrm{CH}$, Mahara JA. Analisis Faktor Lingkungan terhadap Perilaku Buang Air Besar Sembarangan Masyarakat Desa Lermatang Kabupaten Maluku Tenggara Barat. J Info Kesehatan. 2019;9(2):139150. https://stikes-surabaya.e-journal.id/infokes/ article/download/98/49

24. Rochaida E. Dampak Pertumbuhan Penduduk terhadap Pertumbuhan Ekonomi dan Keluarga Sejahtera di Provinsi Kalimantan Timur. Forum Ekonomi. 2016;18(1):14-24. http://journal.feb. unmul.ac.id/index.php/FORUMEKONOMI/article/ view/42

25. Mardotillah M, Gunawan B, Soemarwoto RS, Raksanagara AS. Peran Faktor Pemungkin dan Penguat pada Akses Jamban Sehat Perkotaan. $J$ Antropologi. 2019;20(2):165-178. https://doi. org/10.25077/jantro.v20.n2.p165-178.2018

26. Yulda A, Fajar NA, Utama F. The Effect of Internal and External Factors to Behavior to do Defecation on Latrine After the Triggering in Working Area of Tanjung Batu Primary Health Care. J IImu Kesehatan Masayarakat. 2017;8(2):109-116. https://doi.org/10.26553/jikm.2016.8.2.109-116

27. Mayor of Surabaya of East Java Province. Regulation of the Mayor of Surabaya No. 48 year 2016 about Position, Organizational Structure, Function and Job Descriptions, also Working Procedures of District Health Office os Surabaya. Local Government Secretary of Surabaya; 2016

28. Ministry of Health of Republic Indonesia. Regulation of Ministry of Health of Republic Indonesia No.3/ MENKES/2014 about Community Based Total Sanitation. Jakarta: Ministry of Health of Republic Indonesia; 2014. http://stbm.kemkes.go.id/app/ news/7558/permenkes-nomor-3-tahun-2014tentang-stbm

29. Kurniawati RD, Saleha AM. Analisis Pengetahuan, Sikap dan Peran Petugas Kesehatan dengan Keikutsertaan dalam Pemicuan Stop BABS. J IImu Kesehatan Masyarakat. 2020;9(2):99-108. https:// doi.org/10.33221/jikm.v9i02.527

30. Heranita L, Lubis NL, Moriza T. Faktor yang Mempengaruhi Perilaku Keluarga dalam Pemanfaatan Jamban di Pemukiman Desa Air Pinang, Kecamatan Simeulue Timur, Kabupaten Simeulue Tahun 2018. J Kesehatan Cehadum. 2019;1(3):15-27. http://www.jkc.puskadokesa.com/ jkc/article/download/27/11 